\title{
Public Employee Strikes: Legalization Through the Elimination of Remedies
}

Although workers employed by private companies have had the right to strike against their employers for many years, ${ }^{1}$ very few states have explicitly granted that right to employees in the public sector. ${ }^{2}$ Many states, however, have passed statutes allowing public employees to organize and to bargain collectively over the terms and conditions of their employment. ${ }^{3}$ Even when these statutes do not explicitly give public employees the right to strike, they call into question the vatidity of common law no-strike rules.

California is one state which has passed such statutes. At common law, public einployees in California had no right to strike in support of their demands concerning the ternis and conditions of their employment ${ }^{4}$ unless they had received statutory authorization. ${ }^{5}$ However, in the 1960's and 1970's the state legislature enacted a number of statutes governing public employee collective bargaining. Public workers are now subject to one or more of six different laws, depending on the type of work they perform and the level of governunent in which they work. ${ }^{6}$

1. Division 1287, Amalgamated Ass'n of St., Elec. Ry. \& Motor Coach Employees v. Missouri, 374 U.S. 74, 82 (1963); NLRB v. Erie Resistor Corp., 373 U.S. 221, 233 (1963). See generally R. GORMAN, BASIC TEXT ON LABOR LAW 296-97 (1976) (explaining the concepts of protected and unprotected activity).

2. See Hanslowe \& Acierno, The Law and Theory of Strikes by Government Employees, 67 CoRnELL L. REv. 1055, 1060 (1982). The authors outline the development of legal views of strikes in the private sector and contrast those views with views of public employee strikes. They then argue that public employee strikes should be legal. The Article's appendix summarizes the public employee statutes of the eight states which permit public employees to strike.

3. For useful summaries of state public employee laws, see Midwest Center for Public Sector Labor Relations, Collective Bargaining in Individual States, MIDWEST MONITOR, July-Aug. 1979, at 4; LABor-Management SERvices ADMinistration, U.S. DeP'T of LABOR, SUMMary of Public Sector labor Relations Policies (1981).

4. City of San Diego v. American Fed'n of State, County \& Mun. Employees (AFSCME), Local 127, 8 Cal. App. 3d 308, 310-11, 87 Cal. Rptr. 258, 259-60 (1970); City of Los Angeles v. Los Angeles Bldg. and Constr. Trades Council, 94 Cal. App. 2d 36, 210 P.2d 305 (1949).

5. Los Angeles Metropolitan Transit Auth. v. Brotherhood of R.R. Trammen, 54 Cal. $2 d$ 684, 355 P.2d 905, 8 Cal. Rptr. 1 (1960).

6. The statutes are the Meyers-Milias-Brown Act, CAL. Gov'r CODE $\$ \S 3500-3510$ (West 1980 \& Supp. 1984) (covering local government employees); the State Employer-Employee Relations Act, CAL. Gov'T CODE $\$ \S 3512-3524$ (West $1980 \&$ Supp. 1984) (covering state employees); the George Brown Act, CAL. Gov't CoDE $\S \S 3525-3536$ (West $1980 \&$ Supp. 1984) (covering other state employees); the Education Employment Relations Act, CAL. Gov'r CoDE $\$ \$ 3540-3549.3$ (West 1980 \& Supp. 1984) (covering public school employees); the Higher Education EinployerEmployee Relations Act, CAL. Gov’r CoDE $\$ \S 3560-3599$ (West 1980 \& Supp. 1984) (covering 
With the exception of a statute covering firefighters, ${ }^{7}$ these laws do not specifically address the right to strike. Although appellate courts have held that the statutes do not grant public employees the right to strike, ${ }^{8}$ the California Supreme Court has refused to resolve the issue.

In 1983, the Cahfornia Supreme Court decided two important cases which bear on the right of public employees to strike: El Rancho Unified School District v. National Education Association, ${ }^{10}$ and International Brotherhood of Electrical Workers, Local 1245 v. Ciity of Gridley. ${ }^{11}$ Although neither of these cases resolves the right to strike issue, both effectively restrict the remedies available to public employers agamst striking employees, and thus reduce the risks public employees run if they strike. Moreover, these decisions demonstrate that the supreme court has begun to take a new analytic approach to public employee strikes.

This Comment approaches public employees' right to strike by evaluatimg the remedies available to employers. Despite the California Supreme Court's declarations that it considers the question open, in fact the court's recent decisions have made strikes a more feasible bargaining tactic for employees. This Comment further suggests that the supreme court's holdings are justifiable interpretations of an ambiguous statutory framework. Although the court has formulated a useful new case-by-case analytic approach based on public employers' remedies, this approach is only a first step toward developing a consistent and rational body of case law to guide lower courts in resolving the vast range of issues that public employee strikes create.

Part I of this Counment outlines the development of public em-

higher education employees); and CAL. LAB. CODE $\$ \S 1960-1963$ (West 1980) (covering firefighters). Commentators have noted that this statutory scheme is neither coherent nor logical. See infra note 24.

7. CAL. LAB. CODE $\S 1962$ (West 1980) provides that:

[Fire Department employees] shall have the right to self-organization, to form, join, or assist labor organizations, to present grievances and recommendations regarding wages, salaries, hours, and working conditions to the governing body, and to discuss the same with such governing body, through such an organization, but shall not have the right to strike, or to recognize a picket line of a labor organization while in the course of the performance of their official duties.

8. See, e.g., Stationary Eng'rs, Local 39 v. San Juan Suburban Water Dist., 90 Cal. App. 3d 796, 153 Cal. Rptr. 666 (1979); Pasadena Unified School Dist. v. Pasadena Fed'n of Teachers, Local 1050, 72 Cal. App. 3d 100, 140 Cal. Rptr. 41 (1977); City and County of San Francisco v. Evankovich, 69 Cal. App. 3d 41, 137 Cal. Rptr. 883 (1977); Almond v. County of Sacramento, 276 Cal. App. 2d 32, 80 Cal. Rptr. 518 (1969).

9. See, e.g., San Diego Teachers Ass'n v. Superior Court, 24 Cal. 3d 1, 7, 593 P.2d 838, 842, 154 Cal. Rptr. 893, 897 (1979); City and County of San Francisco v. Cooper, 13 Cal. 3d 898, 912, 534 P.2d 403, 412, 120 Cal. Rptr. 707, 716 (1975); In re Berry, 68 Cal. 2d 137, 151, 436 P.2d 273, 283, 65 Cal. Rptr. 273, 283 (1968).

10. 33 Cal. 3d 946, 663 P.2d 893, 192 Cal. Rptr. 123 (1983).

11. 34 Cal. 3d 191, 666 P.2d 960, 193 Cal. Rptr. 518 (1983). 
ployees' right to strike in California and summarizes the facts and holdings of the $E l$ Rancho and Gridley decisions. Part II analyzes the effect of these two supreme court cases on the remedies available to public sector employers. Part II further evaluates the major arguments agamst allowing public employees the riglit to strike in California, and argues that simce neither the common law nor the statutory collective bargaming sclieme enacted by the California Legislature make public employee strikes illegal, the supreme court is justified in reducing employer remedies. Part III discusses the problems the California Supreme Court will encounter im applying its mode of analysis to the tremendous variety of strike situations whicl can arise.

I

\section{The Development of Public Employees' Right to STRIKE IN CALIFORNIA}

\section{A. Prior Case Law and the Enactment of Statutes}

Public employees in the Umited States have not been granted the same rights as employees of private companies. Private sector employees covered by federal labor law liave the riglit to organize, bargam collectively, and "engage in otlier concerted activities for the purpose of collective bargaining or other mutual aid or protection." 12 The "concerted activities" language lias been interpreted as including most types of strikes. ${ }^{13}$ By contrast, in all but eiglit states, either the legislature or the courts have declared public employee strikes illegal. ${ }^{14}$

\section{California Case Law}

Two inajor decisions ostensibly stand for the proposition that public employee strikes are illegal in California. ${ }^{15}$ In 1949, an appellate court held in City of Los Angeles v. Los Angeles Building and Construc-

12. 29 U.S.C. $§ 157$ (1982).

13. Los Angeles Metropolitan Transit Auth. v. Brotherhood of R.R. Trainmen, 54 Cal. 2d 684, 689, 355 P.2d 905, 907, 8 Cal. Rptr. 1, 3 (1960). The right to strike is not absolute even among private sector employees. Dorchy v. Kansas, 272 U.S. 306 (1926). It is a statutory right. Division 1287, Amalgamated Ass'n of St., Elec. Ry. \& Motor Coach Employees v. Missouri, 374 U.S. 74, 82 (1963); NLRB v. Erie Resistor Corp., 373 U.S. 221, 233 (1963); see also R. GoRMAN, supra note 1, at 210-11 (discussing the right to strike in reference to the constitution). Among the range of actions commonly called "strikes," some will be deemed protected activities while others will be held unprotected. See generally id. at 296-325 (covering protected and unprotected activity). And even in the case of those strikes deemed protected, some employer counterneasures are allowed. See, e.g., Boys Markets, Inc. v. Retail Clerks Union, Local 770, 398 U.S. 235 (1970).

14. Hanslowe \& Acierno, supra note 2, at 1060.

15. Los Angeles Metropolitan Transit Auth. v. Brotherhood of R.R. Traininen, $54 \mathrm{Cal} .2 \mathrm{~d}$ 684, 355 P.2d 905, 8 Cal. Rptr. 1 (1960); City of Los Angeles v. Los Angeles Bldg. and Constr. Trades Council, 94 Cal. App. 2d 36, 210 P.2d 305 (1949). 
tion Trades Council ${ }^{16}$ that the City of Los Angeles had no legal obligation to bargain collectively with its einployees. Thus, the court found that allowing thein to strike would be inconsistent with the public policy expressed in the city charter favoring administrative regulation of labor relations. ${ }^{17}$ The court reasoned that "[t]he employer-employee relationship in the city's service is governed by statutory law and administrative regulation; it is not fixed, either in whole or in part, by contract, as in the field of private industry." 18

A decade later, the Califorina Supreme Court decided Los Angeles Metropolitan Transit Authority v. Brotherhood of Railroad Trainmen. ${ }^{19}$ The high court first noted that in the absence of legislative authorization, pubhic employees generally do not have the right to strike. ${ }^{20} \mathrm{How}$ ever, the mam issue im the case was whether the state statute creating the Los Angeles Transit Authority gave its eunployees such a right. The court held that it did. The court noted that the statute contamed exactly the same "concerted activities" language which had been construed to grant einployees the right to strike under analogous federal statutes. ${ }^{21}$ The court distinguished other cases, including Los Angeles Trades Council, on the ground that those cases did not involve employees specifically authorized by statute to bargain collectively and engage in other concerted activities. ${ }^{22}$

\section{Statutory Enactments and Judicial Construction}

After these early cases the California Legislature enacted a series of statutes governing employer-employee relationships in the public sector. $^{23}$ These statutes are still im effect. Despite what one commentator has called the "lack of thoughtful planning"24 behind the statutory scheine, these six statutes do provide a framework for determming the

16. 94 Cal. App. 2d 36, 210 P.2d 305 (1949).

17. Id. at 46,210 P. $2 \mathrm{~d}$ at 311 . The court also mentioned two general arguments against allowing public sector strikes: that public employee strikes constitute a rebellion against constituted authority, and that such strikes luurt the public interest in maintaining government services. Id. at 48-49, 210 P.2d at 312-13. For a fuller discussion of these arguments and their corresponding counterarguments, see Burton \& Krider, The Role and Consequences of Strikes by Public Employees, 79 YALE L.J. 418 (1970); Hanslowe \& Acierno, supra note 2, at 1061-78; Wellington \& Winter, More on Strikes by Public Employees, 79 YALE L.J. 441 (1970); Wellington \& Winter, The Limits of Collective Bargaining in Public Employment, 78 YALE L.J. 1107 (1969) [hereinafter cited as Wellington \& Winter, Limits of Collective Bargaining].

18. Los Angeles Trades Council, 94 Cal. App. 2d at 44, 210 P.2d at 310.

19. 54 Cal. 2d 684, 355 P.2d 905, 8 Cal. Rptr 1 (1960).

20. Id. at $687,355 \mathrm{P} .2 \mathrm{~d}$ at $906,8 \mathrm{Cal}$. Rptr. at 2 .

21. Id. at 688-89, 355 P.2d at 907, 8 Cal. Rptr. at 3-4.

22. Id. at 691,355 P.2d at 908-09, 8 Cal. Rptr. at 5.

23. See supra note 6 .

24. Grodin, Public Employee Bargaining in California: The Meyers-Milias-Brown Act in the Courts, 23 Hastings L.J. 719, 721 (1972). 
parties' respective rights in labor disputes. For example, the MeyersMilias-Brown Act (MMBA) grants public employees the right to organize, ${ }^{25}$ imposes a duty on both employees and employers to meet and confer in good faith, ${ }^{26}$ and requires mediation of disputes. ${ }^{27}$ Similarly, the Educational Employment Relations Act (EERA) establishes a Pubhic Employment Relations Board (PERB) ${ }^{28}$ to regulate disputes between public schools and their employees. EERA further describes the duties and powers, ${ }^{29}$ lists employer and employee unlawful practices, ${ }^{30}$ and details impasse resolution procedures. ${ }^{31}$ Of the six statutes, only the one pertaining to firefighters explicitly demes public employees the right to strike, ${ }^{32}$ none of the others explicitly addresses the issue. ${ }^{33}$

California appellate courts have consistently held that these statutes do not grant public employees the right to strike. They have therefore concluded, following Los Angeles Metropolitan Transit Authority, that since public employee strikes are not authorized by statute, they remain illegal. These courts have granted numerous remedies to employers beset by such "illegal" strikes. ${ }^{34}$

Among the court-sanctioned remedies available to employers is the termination of striking workers. For example, im 1969, Sacramento County civil service employees went on strike, claiming that their employer was violating the George Brown $\mathrm{Act}^{35}$ by not negotiating in good faith. The county fired them for being absent without leave. The appellate court held that the workers were not entitled to reinstatement; the employer's violations did not justify the strike. ${ }^{36}$ Ten years later, in Stationary Engineers, Local 39 v. San Juan Suburban Water District, ${ }^{37}$ the same appellate court upheld the termination of commumity service district employees who went on strike to protest an alleged violation of the MMBA by their employer. ${ }^{38}$

The courts have also granted employers imjunctive relief. In Los Angeles Unified School District $v$. United Teachers, ${ }^{39}$ an appellate court upheld an injunction against a teachers' strike. The court found that

25. CaL. Gov't CODE $\S 3502$ (West 1980 \& Supp. 1984).

26. Id. \& 3505 .

27. Id. $\S 3505.2$.

28. Id. $\S 3541$.

29. Id. $\S 3541.3$.

30. Id. $\$ \S 3543.5-3543.6$.

31. Id. $\$ \$ 3548-3548.8$.

32. See supra note 7 .

33. There is no provision in any of the other five statutes referring explicitly to strikes.

34. See cases cited supra note 8.

35. See supra note 6.

36. Almond v. County of Sacrainento, 276 Cal. App. 2d 32, 36, 80 Cal. Rptr. 518, 521 (1969).

37. 90 Cal. App. 3d 796, 153 Cal. Rptr. 666 (1979).

38. Id. at 801,153 Cal. Rptr. at 668 .

39. 24 Cal. App. 3d 142, 100 Cal. Rptr. 806 (1972). 
the rule prohibiting strikes by public einployees was well established, and noted that the counterarguinents had been "exhaustively treated."40 Similarly, another appellate court upheld an injunction against striking county employees on the ground that public employee strikes, even if peaceful, are illegal and may be enjoined. ${ }^{41}$

A third remedy the appellate courts have allowed employers is damages. In Pasadena Unified School District v. Pasadena Federation of Teachers, Local 1050,42 an appellate court reaffirmed earlier holdings that public employee strikes are illegal. ${ }^{43}$ However, it then went further and held that a union representing striking teachers was liable for damages in tort on two theories. First, the court found that the union could be found liable for interference with contractual relations. ${ }^{44} \mathrm{Sec}-$ ond, the court ruled that the conduct of an illegal strike was itself a tort for which damages could be recovered. ${ }^{45}$

Unlike the California appellate courts, the California Supreme Court has consistently refused to rule whether public employee strikes are legal under the various statutes. ${ }^{46}$ The court has either refused to hear such cases ${ }^{47}$ thus allowing the appellate court opinions to stand, or it has decided the cases on other grounds while leaving the crucial question open. ${ }^{48}$

40. Id. at 146,100 Cal. Rptr. at 808 .

41. City and County of San Francisco v. Evankovich, 69 Cal. App. 3d 41, 49, 137 Cal. Rptr. 883, 887-88 (1977). The union attempted to distinguish the earlier case of Trustees of Cal. State Colleges v. Local 1352, San Francisco State College Fed'n of Teachers, 13 Cal. App. 3d 863, 92 Cal. Rptr. 134 (1970), on the ground that the strike at San Francisco State, unlike that in Evankovich, had involved violence. The court fouud the distimction immaterial. 69 Cal. App. $3 \mathrm{~d}$ at 49,137 Cal. Rptr. at $887-88$.

42. 72 Cal. App. 3d 100, 140 Cal. Rptr. 41 (1977).

43. Id. at 105-07, $140 \mathrm{Cal}$. Rptr. at $44-45$.

44. Id. at $111,140 \mathrm{Cal}$. Rptr. at 48 . The determination that the strike in question was illegal was esseutial to this claim. The court stated that "[1]abor umions are privileged to induce breach of coutract or to interfere with contractual relationships by engaging in lawful concerted activity. Such privilege, however, does not protect the union when either the object or the means of the concerted action is unlawful." $I d$. at 110-11, 140 Cal. Rptr. at 47.

45. Id. at 112-13, 140 Cal. Rptr. at $48-49$.

46. Los Angeles Metropolitan Transit Auth. v. Brotherhood of R.R. Trainmen, 54 Cal. 2d 684, 355 P.2d 905, 8 Cal. Rptr. 1 (1960).

47. See, e.g., Pasadena Unified School Dist. v. Pasadena Fed'n of Teachers, 72 Cal. App. 3d 100, 114, 140 Cal. Rptr. 41, 41 (1977); Los Angeles Unified School Dist. v. United Teachers, 24 Cal. App. 3d 142, 146, 100 Cal. Rptr. 806, 806 (1972); Trustees of the Cal. State Colleges v. Local 1352, San Francisco State College Fed'n of Teachers, 13 Cal. App. 3d at 863, 868, 92 Cal. Rptr. 134, 137 (1970); City of San Diego v. American Fed'n of State, County and Mun. Employees, Local 127, 8 Cal. App. 3d 308, 318, 87 Cal. Rptr. 258 (1970); Almond, 276 Cal. App. 2d at 39, 80 Cal. Rptr. at 523.

48. See cases cited supra note 9. 


\section{B. The El Rancho and Gridley Decisions}

\section{El Rancho}

In El Rancho Unified School District v. National Education Association $^{49}$ the supreme court faced the question whether an administrative agency had exclusive jurisdiction over a school district's complamt for damages resulting from a teachers' strike led by noncertified employee organizations. The Education Employment Relations Act (EERA) ${ }^{50}$ created a five-meinber Public Einployment Relations Board (PERB) to deal with unfair labor practice claims and other disputes mvolving public school einployees. ${ }^{51}$ EERA also provided that an employee organization could become the exclusive representative of the employees in dealing with their employer by becoming either recognized by the employer or certified by PERB. ${ }^{52}$ The case arose out of a four-week strike by El Rancho school district teachers which broke out in Septennber of 1976, shortly after EERA was enacted. ${ }^{53}$ The organizations leading the strike were neither recognized nor certified as the teachers' exclusive representatives. ${ }^{54}$

Following the strike, the school district filed an unfair labor practice charge with PERB, claiming that the unions had violated two provisions of EERA. While the administrative proceedings were pending, the school district filed a tort action against the unions in Los Angeles County Superior Court. The unions demurred to the complaint on the ground that the court lacked jurisdiction over the subject matter of the action. This contention eventually reached the California Supreme Court. ${ }^{55}$

The supreme court ruled in favor of the umions. In sustaining the unions' demurrer to the school district's complaint, the court held that EERA divests the superior courts of jurisdiction to hear a school district's complaint for damages arising out of a teachers' strike led by noncertified unions. ${ }^{56}$

The court's reasoning in $E l$ Rancho is based on the preemption doctrine, a concept borrowed from federal labor law. Under federal law, the National Labor Relations Board (NLRB) has jurisdiction over all natters which arguably mvolve activities either protected or prohib-

49. 33 Cal. 3d 946, 663 P.2d 893, 192 Cal. Rptr. 123 (1983).

50. Education Employment Relations Act, CAL. Gov'T CODE $\$ \S 3540-3549.3$ (West 1980 \& Supp. 1984).

51. CAL. Gov't CodE $\$ 3541$ (West 1980 \& Supp. 1984).

52. Id. $\$ \S 3543.1,3544.1,3544.7$.

53. El Rancho, 33 Cal. 3d at 948-49, 663 P.2d at 893-94, 192 Cal. Rptr. at 123-24.

54. Id.

55. The court outlines the extensive procedural history of this case. Id. at 949-52,663 P.2d at $894-96,192$ Cal. Rptr. at 124-26.

56. Id. at 961,663 P.2d at 902,192 Cal. Rptr. at 132. 
ited by sections 7 or 8 of the National Labor Relations Act (NLRA). ${ }^{57}$ For example, if a union alleges that an employer is discrimmating agamst union members im its hiring policies, the NLRB has jurisdiction over the dispute, since such discrimination is a violation of section $8(a)(3)$ of the NLRA. ${ }^{58}$ This rule is aimed at avoiding conflict in the regulation of labor-management relations both between federal and state law and between the courts and the administrative agency (the NLRB). ${ }^{59}$

The California Supreme Court had earher applied this preemption concept to disputes involving state public employees in San Diego Teachers Association v. Superior Court. ${ }^{60}$ In that case the jurisdictional conflict was also between the state courts and PERB. The teachers' association contended that the superior court's restraining order and mjunction against the teachers' strike were invalid because the school district had failed to exhaust its EERA remedies. ${ }^{61}$ In applying its preeinption analysis, the court first deternined that the strike in question was arguably an unfair practice prohibited by the EERA. ${ }^{62}$ Next, the court found that PERB could furnish rehef equivalent to the remedies available in any trial court. ${ }^{63}$ Finally, the court analyzed the purposes of EERA and found that the state legislature intended PERB to have exclusive jurisdiction over remedies against strikes that it could properly find were unfair practices. ${ }^{64}$ Thus, the court held that PERB had exclusive jurisdiction to enjoin strikes by public school employee organizations recognized or certified as exclusive representatives under EERA. ${ }^{65}$

In El Rancho the supreine court again used the San Diego Teachers approach, though it emphasized one new eleinent. Relying on the federal preemption doctrine, the court asked whether EERA arguably prohibited or protected the strike. The justices turned first to the "prohibited" branch of the test ${ }^{66}$ and concluded that for two reasons, the strike was arguably prohibited by the EERA. First, they decided that PERB might find that the teachers were induced to participate in the strike against their will and by illegal means, both in violation of

57. 29 U.S.C. \$§ 157, 158 (1982); see San Diego Bldg. Trades Council v. Garmon (Garmon II) 359 U.S. 236 (1959). See generally R. GORMAN, supra note 1, at 766-87 (discussion of preemption of state regulation, including the exceptions to the Garmon doctrine).

58. 29 U.S.C. \& 158(a)(3) (1982).

59. See R. GORMAN, supra note 1 .

60. 24 Cal. 3d 1, 593 P.2d 838, 154 Cal. Rptr. 893 (1979).

61. Id. at 3, 593 P.2d at 840,154 Cal. Rptr. at 895 .

62. Id. at 8,593 P.2d at $842-43,154$ Cal. Rptr. at 898 .

63. Id. at 11, 593 P.2d at $844-45,154$ Cal. Rptr. at $899-900$.

64. Id. at 12-14, 593 P.2d at 845-47, 154 Cal. Rptr. at 900-02.

65. Id. at 14, 593 P.2d at $846-47,154$ Cal. Rptr. at 902 .

66. El Rancho, 33 Cal. 3d at 954, 663 P.2d at 897, 192 Cal. Rptr. at 127. 
EERA. ${ }^{67}$ Second, they found that the employee organizations might have violated EERA by inducing the public school employer to give undue support to noncertified unions. ${ }^{68}$ Noncertified unions do not have the right to act as the employees' exclusive representative in dealing with employers, and employers have a duty to negotiate only with exclusive representatives. ${ }^{69}$ The court reasoned that by ineeting and negotiating with noncertified unions, the school district arguably gave unlawful support to these organizations. ${ }^{70}$

After concluding that the unions' actions might be prohibited under EERA's unfair practice provisions, the court looked at an element which had not been mentioned in San Diego Teachers: whether the controversy presented to the state court was identical to that which could have been presented to PERB. ${ }^{71}$ The enployer argued that PERB would deal only with unfair labor practices, and not the harm caused by the allegedly illegal strike. However, the supreme court rejected this distinction and asserted that PERB, like the court, would examine the illegality of the strike; in any case, since PERB's interests were the same as the public's, PERB would certainly consider what the employer called "the larger harm."72 Since the strike was arguably prohibited by the EERA and the controversy that could have been presented to PERB was identical to that which was presented in court, the El Rancho strike satisfied the "prohibited" branch of the preemption test. ${ }^{73}$

As an independent and alternative ground for preemption, the supreine court found that the strike also satisfied the "protected" branch of the test. ${ }^{74}$ To determine that the El Rancho strike was arguably protected by the EERA, the court borrowed another concept froin federal labor law: the distinction between economic strikes and unfair labor practice strikes. ${ }^{75}$ Under federal law, workers striking in re-

67. Id. at 954, 663 P.2d at 898, 192 Cal. Rptr. at 128. CAL. Gov'T CoDE $\S 3543.6(\mathrm{~b})$ (West 1980) provides that it shall be unlawful for an employee organization to "[i]mpose or threaten to impose reprisals on employees, to discriminate or threaten to discriminate against employees, or otherwise to interfere with, restram, or coerce employees because of their exercise of rights guaranteed by this chapter."

68. El Rancho, 33 Cal. 3d at 955-56, 663 P.2d at 128-29, 192 Cal. Rptr. at 898-99. CAL. Gov'T CoDE $§ 3543.6$ (a) (West 1980) provides that it shall be unlawful for an employee organization to "[c]ause or attempt to cause a public school employer to violate Section 3543.5." Section 3543.5 lists employer unlawful practices, one of which is contributing financial or other support to an employee organization. CAL. Gov'T CODE $\$ 3543.5$ (d) (West 1980).

69. CAL. Gov'T CODE $\$ \S 3543.1$ (a), 3543.3 (West 1980).

70. El Rancho, 33 Cal. 3d at 955-56, 663 P.2d at 898-99, 192 Cal. Rptr. at 128-29.

71. Id. at 956, 663 P.2d at 899,192 Cal. Rptr. at 129.

72. Id. at 957,663 P.2d at 900,192 Cal. Rptr. at 130.

73. $I d$.

74. Id. at $958-59,663$ P.2d at 901,192 Cal. Rptr. at 130-31.

75. Id. at 958,663 P.2d at 900,192 Cal. Rptr. at 130. 
sponse to unfair labor practices receive greater job protection than do workers striking over economic issues. ${ }^{76}$ The court reasoned that although EERA does not provide express protection for economic strikes, a strike protesting the employer's unfair labor practices is arguably protected by the statute. The court pointed out that PERB has discretion to withhold and pursue remedies based on whether or not the remedy will effectuate EERA's purposes. Because the statute expressly prohibits employer unfair practices, the court found that PERB inight deny remedies to employers who had brought on a strike by engaging im these practices. ${ }^{77}$

Since the El Rancho strike was both arguably prohibited and arguably protected by the EERA, the supreme court concluded that PERB preempted the superior court's jurisdiction. ${ }^{78}$ It found that EERA had established a "coinprehensive scheme of law, remedy, and administration"79 which should be protected from conflicting judicial regulation of public employment. Court action should be allowed only when PERB cannot provide a "full and effective remedy." 80

Following its San Diego Teachers analysis, the court then compared the relief available in court to the relief PERB could furnish. In San Diego Teachers, the court liad asked whether PERB could furnish relief equivalent to that which could be provided judicially. In $E l$ Rancho the court changed the test slightly, asking whether PERB could provide full and effective relief. ${ }^{81}$ Because PERB's ability to seek injunctions was clear, the issue of equivalent relief was no great obstacle to finding PERB jurisdiction in San Diego Teachers. However, it is not yet clear whether PERB can award damages. ${ }^{82}$ Thus, the employer's demand for damages in El Rancho provided the court an opportunity to define more fully PERB's relief powers. However, the court sidestepped this issue and found PERB's relief powers "full and effective," witliout defining their precise scope. The court einpliasized the superiority of the remedies clearly available to PERB and the flexibility of an administrative agency compared to the courts. It concluded that PERB could give full and effective, if not identical, relief for all clamis, and therefore it had exclusive initial jurisdiction to determine "what, if any,

\footnotetext{
76. See, e.g., Mastro Plastics Corp. v. NLRB, 350 U.S. 270, 278 (1956).

77. El Rancho, 33 Cal. 3d at 958-59, 663 P.2d at 900-01, 192 Cal. Rptr. at 130-31.

78. Id. at $960,663 \mathrm{P} .2 \mathrm{~d}$ at $901,192 \mathrm{Cal}$. Rptr. at 131.

79. Id. at 960, 663 P.2d at 902, 192 Cal. Rptr. at 132. The court here calls PERB's remedial scheme "comprehensive." However, one should not take this statement to mean that PERB can give all remedies. See infra text accompanying notes 114-20.
}

80. El Rancho, 33 Cal. 3d at 960-61, 663 P.2d at 902, 192 Cal. Rptr. at 132.

81. Id.

82. See infra text accompanying notes $114-20$. 
remedies should be pursued." 83

The effect of this decision was to extend the area preempted by PERB from merely injunctions, which San Diego Teachers covered, to damages. Because the strikes in $E l$ Rancho were arguably prohibited or protected by EERA, the court found that PERB had exclusive jurisdiction over all claims arising out of the strike. And since the statutory scheme was meant to cover all remedies, it should be PERB, not the courts, which determines what remedies to give (even if some remedies are beyond PERB's power). In effect, the supreme court found that the facts of the case, and not the remedy sought in the pleadings, determine whether PERB preempts the courts.

Justice Richardson disagreed. ${ }^{84}$ Proceeding froin the premise that public employee strikes are illegal, he concluded that courts should "retain their traditional jurisdiction to restrain and punish illegal public strikes." ${ }^{85}$ Justice Richardson feared that PERB could sanction or encourage strikes if it had jurisdiction over them. ${ }^{86}$

\section{IBEW v. Gridley}

International Brotherhood of Electrical Workers, Local Union 1245 v. City of Gridley ${ }^{87}$ involved a different einployer sanction and a different statute. This case also arose from a strike. After an impasse developed in collective bargaining between the City of Gridley and a union representing city employees, eighteen public works, fire, and finance department employees went on strike. ${ }^{88}$ The city reacted by notifying the union that it was revoking the union's recognition ${ }^{89}$ as a bargaining representative. The city based the revocation on a resolution it liad adopted four years earlier which declared public employee strikes unlawful and gave the city authority to suspend or revoke the recognition of employee organizations that encourage or condone a strike. ${ }^{90}$ The

83. El Rancho, 33 Cal. 3d at 961, 663 P.2d at 902, 192 Cal. Rptr. at 132.

84. Justice Richardson concurred in the judgmeut, "but only under the compulsion of San Diego Teachers [citations] in which I dissented." Id. at 961, 663 P.2d at 903, 192 Cal. Rptr. at 133 (Richardson, J., concurring).

85. Id. at 962,663 P.2d at 903,192 Cal. Rptr. at 133 (Richardson, J., concurring). Justice Richardson's approach to the issue is best presented in his dissenting opinion in San Diego Teachers, 24 Cal. 3d at 14, 593 P.2d at 847, 154 Cal. Rptr. at 902 (Richardson, J., dissenting).

86. El Rancho, 33 Cal. 3d at 962, 663 P.2d at 903, 192 Cal. Rptr. at 133; see also San Diego Teachers, 24 Cal. 3d at 20-21, 593 P.2d at 851, 154 Cal. Rptr. at 906 (Richardson, J., dissenting).

87. 34 Cal. 3d 191, 666 P.2d 960, 193 Cal. Rptr. 518 (1983).

88. Id. at 196, 666 P.2d at 961,193 Cal. Rptr. at 519.

89. See CAL. Gov'т CODE $\$ \S 3501$ (b), 3503, and 3507 (West 1980 \& Supp. 1984), which provide rules by which a public agency recogmizes an employee organization as a bargaining agent.

90. Gridley, 34 Cal. 3d at 195-96, 666 P.2d at 961-62, 193 Cal. Rptr. at 519-20. This resolution was adopted before any of the city's einployees were represented by a recognized einployee organization. The city argued that the union had agreed to the resolution's provisions and there- 
union filed an action against the city, seeking a meet-and-confer order and an injunction reinstating the fired employees. ${ }^{91}$ The union's request was based on the Meyers-Mihas-Brown Act (MMBA), ${ }^{92}$ which is intended to regulate relations between local government employees and their employers. ${ }^{93}$ The union argued that the city's revocation of the union's status as recognized bargaining agent in retaliation for the strike was imconsistent with the MMBA. ${ }^{94}$ There was no question of preemption by an administrative agency simce the MMBA does not refer to PERB or any other such organization. The MMBA does, however, require a public enployee representative to be recognized by the public agency/employer with which it will bargain in order to represent local government employees. 95

The supreine court ruled in favor of the union. Although the majority held that revocation was impermissible in this situation, it did not find that revocation "would necessarily be inappropriate in all situations." 96

The supreine court's reasoning is largely an atteinpt to test a specific employer's reinedy against the goals of a statute as a whole. The court first tested the remedy of revocation against a specifically enuinerated aim of the MMBA: proinoting the "einployees' right to join and participate in the activities of einployee organizations 'of their own choosing." "97 Since the state legislature equated recognition of employee organizations with representation of einployees, allowing local governments to revoke recognition would allow thein to interfere with one of the central goals of the statute. ${ }^{98}$

In addition to finding the employer's chosen reinedy in conflict with the goal of einployee choice, the court also found it inconsistent with another statutory purpose: the promotion of full communication between public employers and their employees. ${ }^{99}$ The court noted that

fore was estopped from contesting the resolution. The court rejected this argument. $1 d$. at 206 n. 19,666 P.2d at 969 n.19, 193 Cal. Rptr. at 527 n.19.

91. Id. at 196, 666 P.2d at 962,193 Cal. Rptr. at 520.

92. CAL. Gov'T CODE $\$ \S 3500-3510$ (West 1980 \& Supp. 1984).

93. Id. $\S 3500$.

94. A second issue in the case was whether non-civil-service enployees who have engaged in the strike were entitled to notice and hearing before disınissal, given the City of Gridley's personnel rules. Gridley fired all 18 striking workers in response to the strike. Gridley, 34 Cal. 3d at 195, 666 P.2d at 962, 193 Cal. Rptr. at 519.

95. CAL. Gov'T CoDE $\$ \S 3501,3503$ (West 1980).

96. Gridley, $34 \mathrm{Cal}$. 3d at 206, 666 P.2d at 969, 193 Cal. Rptr. at 527. The court left open whether the sanction inight be appropriate in cases of violent strikes.

97. Id. at 199, 666 P.2d at 964, 193 Cal. Rptr. at 522. This purpose is histed in CAL. Gov'T CODE $\S 3500$ (West $1980 \&$ Supp. 1984).

98. Gridley, 34 Cal. 3d at 200-01, 666 P.2d at 964-65, 193 Cal. Rptr. at 522-23.

99. Id. at 201,666 P.2d at 965, 193 Cal. Rptr. at 523. This purpose is listed in CAL. Gov'T CODE $\S 3500$ (West 1980 \& Supp. 1984). 
by revoking the union's recognition at the outset of the strike, the City of Gridley severed a major line of communication at the moment communication was most needed. ${ }^{100}$ Since the revocation defeated the purposes of the MMBA, the court found it an impermissible remedy. ${ }^{101}$

In this case, Justice Richardson was the only dissenter. ${ }^{102}$ As in $E l$ Rancho, he argued that public employee strikes are illegal and should not be condoned. He further found that the MMBA did not specifically rule on whether an employer could revoke a union's recognition "for just cause," therefore, local regulations, such as the Gridley resolution, should govern. ${ }^{103}$

\section{II}

\section{ANALYSIS OF EL RANCHO AND GRIDLEY}

\section{A. Judging the Legality of a Strike from the Remedies Perspective}

Most commentators regard the issue of the legality of public employee strikes as an either-or proposition. ${ }^{104}$ Such an approach treats public employee strikes as "legal" or "illegal" as though these are mutually exclusive categories.

This approach to public employee strikes is not adequate to describe precisely the concept of the right to strike. The most important issue to the parties involved in employer-employee relations is not so much the label attached to their actions, but rather the legal consequences that follow from those actions. Even if a particular strike is deemed "legal," employees are inore likely to be deterred froin exercising their right to strike if the employer has effective remedies at his disposal. Conversely, where strikes are "illegal" but the employer's remedies are not too onerous, employees may consider the strike a viable course of action. For example, a "quickie strike"105 by employees covered by federal law is legal; but it is deemed an "unprotected" activity and the employer may lawfully discharge striking employees. ${ }^{106}$ And even where courts have held the activity "protected"-as in a

100. Gridley, 34 Cal. 3d at 201, 666 P.2d at 965,193 Cal. Rptr. at 523.

101. Id. at 195, 202, 666 P.2d at 961, 966, 193 Cal. Rptr. at 519, 524.

102. Id. at 210,666 P.2d at 971,193 Cal. Rptr. at 529 (Richardson, J., concurring and dissenting).

103. Id. at 212, $666 \mathrm{P} .2 \mathrm{~d}$ at $973,193 \mathrm{Cal}$. Rptr. at 531 (Richardson, J., concurring and dissenting).

104. See, e.g., Wellington \& Winter, Limits of Collective Bargaining, supra note 17; Comment, Strikes by Public Employees: The Consequence of Legislative Inattention, 20 SANTA CLARA L. REv. 945 (1980).

105. A "quickie strike" is an intermittent work stoppage or a slowdown by which workers attempt to exert pressure on the employer without calling an all-out strike. R. GoRMAN, supra note 1 , at 318.

106. See NLRB v. Montgomery Ward \& Co., 157 F.2d 486, 496 (8th Cir. 1946); R. Gorman, supra note 1 , at 318 . 
strike over economic demands-the employer can permanently replace the strikers, and the strikers have limited reinstatement rights. ${ }^{107}$ In these two situations the einployees' actions are "legal," but those actions could lead to severe consequences for the individuals involved.

This is not to say that these labels are entirely irrelevant. The characterization of public employee strikes as legal or illegal will affect the remedies available to einployers faced with strikes. ${ }^{108}$ For example, the California appellate courts, proceeding from the premise that pubhic employee strikes are illegal, are willing to grant employers a wide range of remedies for public employee strikes.

But reliance on these labels could lead one to conclusions that are not only imprecise, but also inaccurate. For example, if one considers public employee strikes to be either legal or illegal, one might conclude that in El Rancho and Gridley the California Supreme Court is refusing to take a stand on the question. After all, the court did not decide the legality of public einployee strikes in either case. But if one views these decisions froin the perspective of remedies, it is clear that the cases do bear on the right to strike. The supreme court is developing a new analytic approach under which it matches each strike situation with remedies consistent with the purposes of the statutory scheme regulating public einployinent. It is only from this latter remedies perspective that this movement in the law toward "legalization" of public employee strikes can be detected.

\section{B. The Effect of $\mathrm{El}$ Rancho and Gridley on Remedies}

Because the California Supreme Court did not find it necessary in either El Rancho or Gridley to decide whether public employees have the right to strike, one cannot conclude from these cases that public employee strikes are now legal in Califormia. However, the decisions effectively reduce both the types of remedies available to an employer and the likelihood that the employer will actually be granted these remedies. Although these decisions do not "legalize" public employee strikes, they reduce the potential risks to striking employees and their unions, and thus make strikes less costly and inore feasible as a bargaining tactic.

107. See NLRB v. Mackay Radio \& Tel. Co., 304 U.S. 333, 345 (1938) (employer may hire permanent replacements for economic strikers); Laidlaw Corp., 171 N.L.R.B. 1366 (1968), enforced, 414 F.2d 99 (7th Cir. 1969), cert. denied, 397 U.S. 920 (1970) (striking worker is still an employee and has priority for his old job or a comparable position upon departure of the permanent replacement if he or she files for unconditional reinstatement).

108. See Hanslowe \& Acierno, supra note 2. 


\section{El Rancho and the Remedies Available in Administrative Proceedings}

The El Rancho ${ }^{109}$ decision has the far-reaching effect of limiting the remedies available to employers in the event of a strike. Although the holding is limited to damage suits against uncertified unions, the court's reasoning can be extended not only to damage suits agamst certified umions, ${ }^{110}$ but also to other remedies that employers inight seek, ${ }^{111}$ and to public employees covered by other statutes. ${ }^{112}$

However, the remedy of damages is most directly affected by the decision. As a result of $E l$ Rancho, public employers will be less likely to obtain damages from striking teachers' unions. ${ }^{113}$ Indeed, if damage suits against all teacliers' unions are found to be within PERB's exclusive jurisdiction, then PERB must be both willing and able to give damages before employers can get this form of relief.

Yet it is still unclear whether PERB is able to give employers damages. The EERA gives PERB wide discretion in cloosing low to deal with claims brought before it. Three subsections of the statute confer on PERB the power to imvestigate unfair practices cliarges and take whatever action it deems necessary to deal with violations. ${ }^{114}$ In their El Rancho brief, the unions argued that PERB is empowered to give remedies similar to those available in court, citing six cases in whicl PERB awarded monetary damages to compensate for unfair labor practices. ${ }^{115}$ However, it is important to note that none of these decisions imposed damages on a union for an illegal strike; all the judgments ordered employers to pay damages to workers who liad brought claims for reinstatement or back wages. ${ }^{116}$

109. El Rancho Unified School Dist. v. National Educ. Ass'n, 33 Cal. 3d 946, 663 P.2d 893, 192 Cal. Rptr. 123 (1983).

110. The only section of the court's reasoning which depends on the certified-noncertified distinction is the argument that the strike was arguably prohibited as a violation of CAL. Gov'T CODE § 3543.6(a) (West 1980 \& Supp. 1984). See El Rancho, 33 Cal. 3d at 955, 663 P.2d at 898, 192 Cal. Rptr. at 128.

111. For example, termination of employees might be a remedy falling within PERB's “comprehensive scheme."

112. For example, the provisions of the Higher Education Einployer-Einployee Relations Act are also administered by PERB. See CAL. Gov'T CODE $\$ 3563$ (West 1980).

113. Although the court did not say so, its decision effectively overruled portions of Pasadena Unified School Dist. v. Pasadena Fed'n of Teachers, Local 1050, 72 Cal. App. 3d 100, 140 Cal. Rptr. 41 (1977), which allowed courts jurisdiction over damage actions against striking unions.

114. CaL. Gov't CODE $\$ 3541.3(\mathrm{i}),(\mathrm{j})$, (n) (West 1980).

115. Respondent's Brief at 10-11, El Rancho Unified School Dist. v. National Educ. Ass'n, 33 Cal. 3d 946, 663 P.2d 893, 192 Cal. Rptr. 123 (1983) (on file with the California Law Review).

116. The brief lists six cases: Newnan-Crows Landing Unified School Dist., 4 PuB. EMPL. REP. (CAL. ED.) (LAB. REL. PRESS) If 11,008, at 21 (Jan. 14, 1980) (Gallery, Hearing Officer) (ordering reinstatement with back pay); San Francisco Commumity College Dist., 3 PuB. EMPL. ReP. (CAL. ED.) (LAB. Rel. PRESs) If 10,127, at 397 (Oct. 12, 1979) (PERB) (ordering payinent of previously authorized salary imcreases and fringe benefits); Santa Monica Community College 
On the other hand, the supreme court implied in El Rancho that damages is one remedy that PERB inay not grant. Comparing PERB's remedies with those of the courts, the supreine court noted that "PERB can provide a 'full and effective'-though not identical-reenedy against such strikes." 117 The court then listed mediation and injunctive relief as two forms of relief PERB may employ, and found that these remedies are more likely than dainages to accomplish legislative goals. ${ }^{118}$ The court further cited with approval a Michigan Supreme Court decision refusing to allow tort remedies to employers. The Michigan court found that such remedies would have a "negative impact" on legislative goals and would encourage "school board inaction."119 Statements such as these could provide the California courts authority for construing PERB's wide discretion as excluding a tort damages remedy. ${ }^{120}$ And even if courts hold that PERB is able to give dannages to employers, the supreme court has clearly stated its preference that PERB limit itself to other remedies.

Although the statute does not inention damages, it explicitly grants PERB the power to issue injunctions, and the supreme court has specifically recognized this remedy as within PERB's powers. ${ }^{121}$ But in $E l$ Rancho the supreme court lessened the risks that injunctions will be used against striking unions. Following its earher decision in San Diego Teachers, the court emphasized PERB's ability to "withhold as

Dist., 3 Pub. Empl. Rep. (CAL. Ed.) (LAB. Rel. Press) If 10,123, at 372 (Sept. 21, 1979) (PERB) (ordering retroactive salary increases to rectify past salary discrimination); Centinela Valley Union High School Dist., 3 Pub. EMPL. Rep. (CAL. Ed.) (LAB. Rel. Press) II 10,011, at 48 (Jan. 3, 1979) (Naiman, Hearing Officer) (ordering payment of previously authorized salary increases); Los Gatos Joint Union High School Dist., 2 Pub. EmPL. ReP. (CAL. Ed) (LAB. Rel. Press) 12133 , at 315 (June 22, 1978) (Becker, Hearing Officer) (ordering reinstatement with back pay); Saddleback Valley Union School Dist., 1 PuB. EMPL. ReP. (CAL. Ed.) (LAB. Rel. Press) 54 (Feb. 10, 1977) (Paule, Hearing Officer) (ordering back pay as remedy for discriminatory refusal to hire). In several of these cases, PERB justified its order of back pay with CAL. Gov'T CoDE $\$ 3541.5$ (c) (West 1980), which explicitly gives PERB power to order reinstatement with back pay. Furthermore, in the Santa Monica case, PERB noted that although $\$ 3541.5$ (c) links back pay with reinstatement, the Supreme Court has interpreted similar language in $\S 10(c)$ of the National Labor Relations Act, 29 U.S.C. $\S 160$ (c) (1976), as allowing back pay awards even in the absence of reinstatement. 3 Pub. EMPL. Rep. (Cal. Ed.) (Lab. Rel. Press) If 10,123, at 377 (citing Radio Officers' Union v. NLRB, 347 U.S. 17 (1954) and Phelps Dodge Corp. v. NLRB, 313 U.S. 177 (1941)).

117. El Rancho, 33 Cal. $3 \mathrm{~d}$ at 961,663 P.2d at 902,192 Cal. Rptr. at 132.

118. Id.

119. Id. (quoting Lamphere Schools v. Lamphere Fed'n of Teachers, 400 Mich. 104, 131, 252 N.W.2d 818, 830 (1977)).

120. An employer might, however, obtain damages in cases where a union's strike is in breach of a no-strike clause. See Fresno Unified School Dist. v. National Educ. Ass'n, 125 Cal. App. 3d 259, 177 Cal. Rptr. 888 (1981) (PERB and courts have concurrent jurisdiction; initial deferral to PERB does not foreclose later court proceedings on the contract breach).

121. CAL. Gov'T CODE $\$ \$ 3541.3(j), 3541.5$ (c) (West 1980); San Diego Teachers Ass'n v. Superior Court, 24 Cal. 3d 1, 13, 593 P.2d 838, 846, 154 Cal. Rptr. 893, 901 (1979). 
well as to pursue, the various remedies at its disposal."122 Thus PERB received the supreme court's blessing to mediate the parties' dispute rather than to seek an imjunction. The court's suggestion that PERB can deny injunctions stands in sharp contrast to the appellate courts' readiness to issue injunctions agaimst "illegal" strikes under the common law. ${ }^{123}$

Even settimg aside the supreme court's hints as to what remedies are appropriate, the switch to PERB jurisdiction mandated by $E l$ Rancho will probably reduce public employers' remedies against strikers. This is because PERB uses a different analytic approach than do the courts. The school district in El Rancho was concerned that in deciding on remedies PERB would not consider the "larger harm"124 caused by the teachers' strike. Although the supreine court correctly found that PERB will consider and try to alleviate the harmful effects of a strike, the more important question remains: How does PERB's approach to remedies differ from that of the courts?

Traditionally the appellate courts have approached the remedy issue by first asking whether the strike was illegal; a determination of "illegality" has generally ineant that any remedy is available to employers. PERB, by contrast, is charged with the task of mvestigating unfair labor practices and determining what action needs to be taken to effectuate the statutory policies. ${ }^{125}$ The supreme court im El Rancho implies that these may be balanced agamst each other: PERB may deny remedies to both sides if the employees' unfair practices and the employer's unfair practices offset eacli other. ${ }^{126}$ The appellate courts have granted remedies with the objective of deterring any strikes unauthorized by statute and therefore "illegal." In El Rancho the supreine court recogmized that PERB will provide only those remedies which effectuate statutory goals such as the deterrence of unfair labor practices. ${ }^{127}$ If teachers' strikes are within PERB's jurisdiction, the fact that they are "illegal" will not mean that employers autoinatically are awarded the remedies they desire.

122. El Rancho, 33 Cal. 3d at 961, 663 P.2d at 902, 192 Cal. Rptr. at 132 (quoting San Diego Teachers, 24 Cal. 3d at 13, 593 P.2d at 846, 154 Cal. Rptr. at 901).

123. See, e.g., City and County of San Francisco v. Evankovich, 69 Cal. App. 3d 41, 137 Cal. Rptr. 883 (1977); Los Angeles Unified School Dist. v. United Teachers, 24 Cal. App. 3d 142, 100 Cal. Rptr. 806 (1972); Trustees of the Cal. State Colleges v. Local 1352, San Francisco State College Fed'n of Teachers, 13 Cal. App. 3d 863, 92 Cal. Rptr. 134 (1970). In these cases a finding of illegahty led directly to the granting of an injunction.

124. El Rancho, 33 Cal. 3d at 957, 663 P.2d at 900, 192 Cal. Rptr. at 130.

125. Cal. Gov't Code $\$ \S 3541.3(i), 3541.5$ (West 1980).

126. See supra text accompanying notes $76,77,122$.

127. El Rancho, 33 Cal. 3d at 958, 663 P.2d at 900, 192 Cal. Rptr. at 130. 


\section{Gridley and the Remedies Available in Court}

The Gridley ${ }^{128}$ case also had the effect of removing potential remedies from the reach of public employers, although it did not go as far as El Rancho. Gridley concerned a single remedy-the revocation of a striking umon's recognition by the public employer. The supreme court held that the employer could not invoke this remedy because it was inconsistent with the stated purposes of the MMBA: ${ }^{129}$ promoting employer-employee coinmunication and employee choice in representation. ${ }^{130}$

The effects of the Gridley case are easier to see than those of $E l$ Rancho. Before Gridley, local governments had revoked their recognition of unions as employee representatives im order to sanction strikers, ${ }^{131}$ Gridley removed revocation from the hist of remedies available to employers under the MMBA. Although the court qualified its denial of this sanction by mdicating that revocation might sometimes be appropriate, the justices appear to have had in mind a situation involving violence and other similar "aggravated misconduct."132

While eliminatimg the revocation of recognition as a permissible sanction, the supreme court reassured employers that other remedies agamst illegal strikes were still available. It histed both injunctions and the dismissal of striking employees as "sanctions which do not interfere with workers' legitmiate rights under the MMBA."133

The court's discussion of permissible remedies is as interesting for what it leaves out as for what it includes. Notably missing from the court's brief list is the remedy of damages. While this omission may result from the fact that none of the appellate court cases previously

128. International Bhd. of Elec. Workers, Local 1245 v. City of Gridley, 34 Cal. 3d 191, 666 P.2d 960, 193 Cal. Rptr. 518 (1983).

129. Meyers-Milias-Brown Act, CAL. Gov'T Code $\S \S 3500-3510$ (West 1980 \& Supp. 1984).

130. Gridley, 34 Cal. 3d at 201-02, 666 P.2d at 965-66, 193 Cal. Rptr. at 523-24.

131. See Ross, Implementation of the Meyers-Milias-Brown Act by California's Counties and Larger Cities, 8 CAl. Pub. Employee Rel. 6 (1971); Reccnt Developments in California Public Jurisdictions, 51 CAL. Pub. EMPloyee Rel. 24, 28-30 (1981).

132. Gridley, 34 Cal. 3d at 202, 666 P.2d at 966, 193 Cal. Rptr. at 524. The court's discussion of a possible exception to the Gridley holding focused on a federal case in which the National Labor Relations Board revoked a union's certification because of violence and inisconduct. The case was Union Nacional de Trabajadores (Carborundum Co. of Puerto Rico), 219 N.L.R.B. 862 (1975), enforced, NLRB v. Union Nacional de Trabajadores, S40 F.2d 1 (1st Cir. 1976), cert. denied, 429 U.S. 1039 (1977).

133. Gridley, 34 Cal. 3d at 204, 666 P.2d at 968, 193 Cal. Rptr. at 526. The court also cited a number of law review articles which describe sanctions potentially available to public employers in the event of a strike. The court premised its offer of injunctions and termination on the determination that a strike was illegal or in violation of contract. If the court were to find in the future that public employee strikes are not illegal, it would probably come to a different result in a sinilar case. 
decided under the MMBA concerned damages, ${ }^{134}$ it might also be evidence of the supreme court's dissatisfaction with the damages remedy in public employee strike cases. ${ }^{135}$

\section{The Supreme Court's Approach in El Ranclio and Gridley}

\section{The Supreme Court Has Abandoned the View that Public Employee Strikes Are Illegal}

The supreme court's decisions in El Rancho and Gridley are a marked departure froin previous case law. Altlough in neither case does the court declare public sector strikes legal, the underlying premise of the court's rcasoning is that such strikes are no longer illegal in the common law sense. The court assumes that neither the case law nor the statutory law makes public sector strikes illegal, and chooses to judge strikes on a case-by-case basis, weighing employers' remedies against the specifically enumerated purposes and the implicit policies of the govcrning statutes.

In their previous decisions, the appellate courts began with the premise that public employee strikes were illegal, either under the common law, or later under the various statutes. ${ }^{136}$ Once the courts had adopted this premise, they made almost any remedy available in order to stop the employees' illegal behavior. Thus einployers could enjoin strikes, obtain damage awards against a group of strikers, or terminate the strikers.

Had the California Supreme Court decided to analyze public employee strikes in this maimer, its El Rancho and Gridley decisions would have been much different. If in $E l$ Rancho the court had assumed that public employee strikes were illegal, it would have been more reluctant to remove them froin the jurisdiction of the courts (which presumably would grant harsher remedies than would PERB). Even if the court had given PERB exclusive jurisdiction, it might liave explicitly authorized a wider range of reinedies mstead of einpliasizing PERB's discretion to deny reinedies. ${ }^{137}$

Similarly, the supreme court could have reached an opposite result

134. Stationary Eng'rs Local 39 v. San Juan Suburban Water Dist., 90 Cal. App. 3d 796, 153 Cal. Rptr. 666 (1979), and Almond v. County of Sacramento, 276 Cal. App. 2d 32, 80 Cal. Rptr. 518 (1969), dealt with employee termmation, while City and County of San Francisco v. Evankovich, 69 Cal. App. 3d 41, 137 Cal. Rptr. 883 (1977), was an injunction case.

135. See supra text accompanying note 119.

136. See cases cited supra note 8.

137. See supra text accompanying note 77 . The court's snggestion that unfair labor practice strikes may be protected implies that a PERB decision to refuse remedies in such a situation would be upheld. Such a ruling is fiatly imconsistent with a view of pnblic employee strikes as per se illegal, and therefore indicates that the California Supreme Court does not hold this view. 
in Gridley had it begun with a premise of illegality. In that case the majority assumed for the purposes of argunent that the strike was illegal, and still found the requested remedy unavailable. ${ }^{138}$ However, if the court had been firmly committed to applymg the label of illegality to the strike, it might have imterpreted the MMBA's statutory purposes as consistent with the remedy of revocation. For example, the court stated that allowing the city to revoke the union's recognition would conflict with the statutory purpose of proinoting full communication between employer and employees, since the severing of ties between the two destroyed a line of communication when it was most needed. ${ }^{139}$ But the court could have found just as easily that the union's strike destroyed communications between the parties, and therefore allowing a stiff sanction would promote good communications in the future.

\section{The Justifications for Finding Public Employee Strikes Illegal in California Are Not Persuasive}

Califoruna courts have given two nuain justifications for finding public employee strikes illegal. First, appellate courts have cited City of Los Angeles v. Los Angeles Building and Construction Trades Council ${ }^{140}$ and Los Angeles Metropolitan Transit Authority v. Brotherhood of Railroad Trainmen ${ }^{141}$ for the proposition that public employee strikes are illegal under the common law. ${ }^{142}$ Second, the courts have found that the legislature intended to perpetuate the common law view in the new statutory sclieme. Thus, the statutes now specify that Labor Code section 923 , which allows strikes by workers in the private sector, ${ }^{143}$ does not apply to public entployees. ${ }^{144}$ Relying on these rationales, the courts have found strikes illegal and granted enployers remedies. ${ }^{145}$

\section{a. The Continuing Validity of Judicial Precedent}

The first case relied on by proponents of the illegality rule, Los

138. Gridley, 34 Cal. 3d at 199 n.7, 666 P.2d at 964 n.7, 193 Cal. Rptr. at 522 n.7. The union had not contested the city's assertion that the strike was illegal.

139. Id. at 201, 666 P.2d at 965, 193 Cal. Rptr. at 523.

140. 94 Cal. App. 2d 36, 210 P.2d 305 (1949).

141. 54 Cal. 2d 684, 355 P.2d 905, 8 Cal. Rptr. 1 (1960).

142. See, e.g., City of San Diego v. American Fed'n of State, County and Mun. Employees Local 127, 8 Cal. App. 3d 308, 310, 87 Cal. Rptr. 258, 259-60 (1970); Almond v. County of Sacramento, 276 Cal. App. 2d 32, 35-36, 80 Cal. Rptr. 518, 520-21 (1969).

143. Los Angeles Metropolitan Transit Auth. v. Brotherhood of R.R. Trainmen, 54 Cal. 2d 684, 687-89, 355 P.2d 905, 906-07, 8 Cal. Rptr. 1, 2-4 (1960).

144. See, e.g. , Pasadena Unified School Dist. v. Pasadena Fed'n of Teachers, Local 1050, 72 Cal. App. 3d 100, 106, 140 Cal. Rptr. 41, 45 (1977); Almond, 276 Cal. App. 2d at 37, 80 Cal. Rptr. at 522 .

145. See, e.g., Pasadena Unified School District, 72 Cal. App. 3d at 110-13, 140 Cal. Rptr. at 47-49; Trustees of the Cal. State Colleges v. Local 1352, San Francisco State College Fed'n of Teachers, 13 Cal. App. 3d 863, 867, 92 Cal. Rptr. 134, 136 (1970). 
Angeles Trades Council, was decided before the passage of the statutes regulating public sector einployment and is therefore no longer binding precedent. That case is premised on a conception of public employeremployee relations in which no statute authorizing collective bargaining exists. In that case, the appellate court observed that statutory law and administrative regulation, as opposed to contract, govern employer-employee relations in the public sector. ${ }^{146}$ In the private sector, by contrast, the parties engage in contract negotiation-collective bargaining. Striking and picketing in support of the employees' position necessarily accoinpany collective bargaining, but should not accompany the setting of terms and conditions of einployinent "by law." The court concluded that the transit authority employees had no right to strike or picket ${ }^{147}$ and granted the employer a temporary injunction. ${ }^{148}$

This rationale for denying the right to strike evaporated once the legislature authorized collective bargaining for public employees. Now public employers and einployees set the terms and conditions of employment "by contract," not "by law." A strike is no longer a direct challenge to government regulations fixing public einployees' wages. ${ }^{149}$

The second case often cited for the proposition that public einployee strikes are illegal did not directly confront the illegality issue. In Los Angeles Metropolitan Transit Authority v. Brotherhood of Railroad Trainmen, ${ }^{150}$ the supreme court stated that in the absence of legislative authorization, public employees in general do not have the right to strike. ${ }^{151}$ This rule only poses the question; it does not answer it. It is still unclear whether the modern statutory scheme authorizes or prohibits public employee strikes. ${ }^{152}$ Just as the supreine court looked to the language of the current statute to ascertain whether the strike in question was legal in Los Angeles Trades Council, so too in El Rancho and Gridley the court is justified in looking to the language of the new statutes to determine whether certain remedies should now be given.

Because neither of these cases holds public employee strikes illegal under the modern statutory scheme, the supreme court is justified in rejecting them as binding authority for that proposition.

\section{b. Statutory Interpretation}

However, in so rejecting these early cases, the supreme court must

146. Los Angeles Trades Council, 94 Cal. App. 2d at 46-47, 210 P.2d at 311.

147. Id. at 46,210 P.2d at 311 .

148. Id. at 50,210 P.2d at 314. The temporary injunction was later inade permanent. See 109 Cal. App. 2d 81, 240 P.2d 16 (1952) (sane case on appeal).

149. See Los Angeles Trades Council, 94 Cal. App. 2d at 44, 210 P.2d at 310.

150. 54 Cal. 2d 684, 355 P.2d 905, 8 Cal. Rptr. 1 (1960).

151. Id. at 687,355 P.2d at 906, 8 Cal. Rptr. at 2 .

152. See supra note 33 . 
still decide whether the modern statutes prohibit public employee strikes. Although the statutes contain no explicit prohibition, proponents of the illegality rule point out that in certain sections, the statutes specifically state that Labor Code section $923,{ }^{153}$ which has been interpreted to give private sector employees the right to strike, does not apply to public employees. ${ }^{154}$ The proponents contend that these sections deinonstrate the legislature's intention to deny public employees the right to strike. ${ }^{155}$ This argument fails for two reasons. First, the main appellate decision construing Labor Code section 923 does not support such a conclusion. In Nutter $v$. City of Santa Monica, ${ }^{156}$ decided before the passage of the modern public employment statutes, a public employees' umion attempted to force an employer to bargam with it. The union argued that Labor Code section 923 mandated collective bargaining for public einployees. However, the court explamed that section 923 embodies the same principle as the National Labor Relations Act, ${ }^{157}$ and that the purpose of section 923 is to "commit the state to participation in a movement whicl has long been under way in the field of national legislation, and generally in state legislation, to improve the status of labor in the field of private industry."158 Therefore, the court held that section 923 applies only to workers in the private sector.

The fact that the new statutes expressly make section 923 inapplicable to public employinent relations adds nothing to the Nutter decision; it simply reaffirms that whatever rights are granted to public einployees should be interpreted without reference to the NLRA-type

153. CAL. LAB. Code $\$ 923$ (West 1971) provides:

In the interpretation and application of this chapter, the public policy of this State is declared as follows:

Negotiation of terms and conditions of labor should result from voluntary agreement between employer and employees. Governmental authority has permitted and cncouraged einployers to organize in the corporate and other forms of capital control. In dealing with such employers, the individual unorganized worker is helpless to exercise actual liberty of contract and to protect his freedom of labor, and thereby to obtain acceptable terms and conditions of employment. Therefore it is necessary that the individual workman have full freedom of association, self-organization, and designation of representatives of his own choosing, to negotiate the terms and conditions of his employment, and that he shall be free from the interference, restraint, or coercion of employers of labor, or their agents, in the designation of such representatives or in self-organization or in other concerted activities for the purpose of collective bargaining or other mutual aid or protection.

154. CAL. Gov'T CODE $\$ 3509$ (MMBA), 3549 (EERA) (West 1980).

155. See San Diego Teachers Ass'n v. Superior Court, 24 Cal. 3d 1, 14, 593 P.2d 838, 847, 154 Cal. Rptr. 893, 902 (1979) (Richardson, J., dissenting); Pasadena Unified School Dist. v. Pasadena Fed'n of Teachers, Local 1050, 72 Cal. App. 3d 100, 140 Cal. Rptr. 41 (1977); see also Almond v. County of Sacramento, 276 Cal. App. 2d 32, 80 Cal. Rptr. 518 (1969) (the MMBA does not constitute legislative authorization of a right to strike).

156. 74 Cal. App. 2d 292, 168 P.2d 741 (1946).

157. Id. at 298,168 P.2d at 745.

158. Id. at 301,168 P.2d at 747. 
"movement" in private sector labor law. In summary, those who favor legalization of public employee strikes may not use section 923 to support their arguments; but those who would like to see public employee strikes prohibited must also look beyond section 923 .

Moreover, the alleged legislative intent to deny public employees the right to strike stands in stark contrast to the broad scope of section 923. Section 923 guarantees private sector employees the right to associate, organize, choose representatives, bargain collectively, and engage in "concerted activities." 159 One cannot conclude that by virtue of bemg mentioned in section 923, all these rights are denied to public enployees; the fact that the new statutes specifically provide for public employee collective bargaining shows that the legislature has found independent reasons, not based on private sector principles, for granting this right. If the legislature intended to exclude only part of the NLRA-type scheme froin public sector law, the present statutory framework does not indicate which rights are to be denied to public employees. On the question of strikes, the statutes are silent.

Proponents of the theory that public sector strikes are illegal might argue that the legislature meant to deny all rights it did not explicitly grant. But it seems unlikely that the legislature would use such a vague and awkward method to prohibit public einployee strikes. Had there been enough votes to flatly prohibit such strikes, the legislature would have adopted language similar to that pertaining to firefighters. ${ }^{160}$ Moreover, there are better explanations for making section 923 inapplicable to public employment. The legislature may have been concerned that an across-the-board application of NLRA principles, wholly apart from the right to strike, could have a disruptive effect on public employer-employee relations. In San Diego Teachers Association, the court recognized the union's arguinent that the legislature's action could be explamed "by a concern that the wholesale introduction of rules protecting collective bargaining in the private sector into the public sector might conflict with tenure and other aspects of public enployment that fall outside the negotiating process mandated by the EERA."161 And in Nutter itself, the appellate court stated that "the elaborate system of laws which constitutes the policy of the state in the domain of public employinent would be largely nullified if the legislation [section 923] should be construed as apphicable to public employment, to the full extent that it is applicable to private employment."162 In short, speculation about the legislature's intent leads only to the con-

159. CAL. Lab. Code $\$ 923$ (West 1971). See supra note 153.

160. Id. § 1962.

161. 24 Cal. 3d 1, 6, 593 P.2d 838, 841, 154 Cal. Rptr. 893, 896 (1979).

162. Nutter, 74 Cal. App. 2d at 301, 168 P.2d at 747. 
clusion that the law on public employee strikes should be understood in isolation from the policies embodied im section 923.

\section{The Supreme Court's Interpretation of Legislative Purpose}

Given that neither the common law nor the statutes provide a definitive statement on strike legality, it is not clear how the supreme court should approach the problem. The most obvious solution is for the legislature to enact more comprehensive and internally consistent legislation regarding public employees. This idea has been pressed by commentators smce the enactment of the present set of statutes. ${ }^{163}$ If the legislature acted, the court would not have to guess at the correct statutory imterpretation. Similarly, the court would not have to face the challenge that it was overreaching its constitutionally granted authority.

But as desirable as legislative action may be, the fact remams that the legislature has not acted to clarify the law. In the meantime public employces contimue to organize, participate in collective bargaming, and use the strike as a collective bargainmg tactic. ${ }^{164}$ Given this situation, it is not only justifiable but necessary for the supreme court to define the rights of employers and employces in the event of a strike. The issues in Gridley and El Rancho would not have arisen had the legislature enacted clearer and more comprehensive legislation. Given that the legislature has "steadfastly reframed from providimg clearcut guidance," 165 the court was right to decide those issues.

Since the statutes provide no guidance on the right to strike, the supreme court has been forced to deduce rules from the statutes as they are presently written. The court has had to weigh strike remedies sought by public employers agaimst either the specifically enumerated purposes of each statute or the broader implied policies of the public employee legislation as a whole. An example of such specifically enumerated purposes is found in the initial section of the MMBA, which outlines three purposes of the act: "to promote full communication between public employers and their employees," "to promote the improvement of personnel management and employer-employee relations within [California's] public agencies," and "to strengthen merit, civil service and other methods of administering employer-employee relations." 166 The Gridley court rejected the employer's chosen remedy of

163. See, e.g., Grodin, supra note 24; Note, The Collective Bargaining Process at the Mumicipal Level Lingers in its Chrysalis Stage, 14 SANTA CLARA L. Rev. 397 (1974).

164. See Comment, supra note 104.

165. El Rancho Unified School Dist. v. National Educ. Ass'n, 33 Cal. 3d 946, 964, 663 P.2d 893, 904, 192 Cal. Rptr. 123, 134 (1983) (Grodin, J., concurring).

166. CaL. Gov't CoDE $\S 3500$ (West 1980 \& Supp. 1984). 
revoking the union's recognition as inconsistent with these purposes. ${ }^{167}$ An example of a more general policy is the encouragement of dispute resolution by collective bargaining. Since all six of the public employee statutes grant the right to bargam collectively, the court could conclude that any scheme of employer remedies should not operate to discourage collective bargaining.

The supreme court will probably contmue to analyze public employee strike cases as it did in El Rancho and Gridley. Although it is possible that the court could go as far as to declare public employee strikes legal, such a decision would draw accusations that the court was usurping legislative powers. It is much easier for the court to judge remedies on a case-by-case basis while rejecting both the assumption that public sector strikes are illegal and the corresponding inference that all remedies should be available to employers.

\section{III}

\section{Problems with the Supreme Court's Approach}

\section{A. Ad Hoc Adoption of Federal Principles}

Although the supreme court's movement toward limiting employer strike remedies is justifiable, the court's methodology is nonetheless troubling. The court is apparently adopting federal labor law principles on an ad hoc basis. The unpredictability of such an approach will make it difficult for the parties involved in public employment disputes to know what course of action to take. Furthermore, the lower courts' task of formulatimg consistent rules will beconie harder to achieve.

This is not to say that it is undesirable to make analogies to federal law in construing state public employee laws. A number of California Supreme Court opinions have held that because federal labor law has often been the prototype for California labor law, it is permissible to look to federal law for guidance in interpreting state provisions with language paralleling that of the federal statutes. ${ }^{168}$ The problem is that the California Supreme Court appears willing to draw analogies to federal law even where the language is not parallel and where the relationship between the federal and state law is unclear. Moreover, the court does not elucidate exactly how much of the federal law it has incorporated.

An example of this ad hoc adoption is the use of the "protected" employee behavior concept in El Rancho. The California Supreme

167. International Bhd. of Elec. Workers, Local 1245 v. City of Gridley, 34 Cal. 3d 191, 202, 666 P.2d 960, 966, 193 Cal. Rptr. 518, 524 (1983).

168. See, e.g., Fire Fighters Union, Local 1186 v. City of Vallejo, 12 Cal. 3d 608, 617, 526 P.2d 971, 977, 116 Cal. Rptr. 507, 513 (1974); Social Workers' Union, Local 535 v. Alameda County Welfare Dep't, 11 Cal. 3d 382, 391, 521 P.2d 453, 459, 113 Cal. Rptr. 461, 467 (1974). 
Court decided that controversies involving arguably protected employee behavior should be handled by an administrative agency (PERB) rather than the courts. ${ }^{169}$ However, the concept of protected activity in federal labor law is crucial to other questions besides those of preeinption; a determination of whether or not certain activity by einployees is protected will often determine the employees' and employers' substantive rights. ${ }^{170}$ For example, workers who are "disloyal" to their company are deemed to have engaged in unprotected behavior, and therefore can be fired. ${ }^{171}$ When the Cahiforuia Supreme Court uses the protected activity concept in its preemption analysis, does it intend to read this "disloyalty" rule into state labor law as well? The court should clarify the breadth of its use of federal analogies.

\section{B. The Limits of Case-by-Case Analysis}

\section{Variations Among Statutes, Employees, Strikes, and Remedies}

An even more fundainental problem with the supreme court's new approach is the tremendous variety of cases the courts will have to decide. An enormous volume of litigation will be necessary to determine the remedies that are permissible in each strike situation. Variations among four major factors-statutes, employees, strikes, and remediescontribute to the multiplicity of possible controversies.

First, six different statutes make up California's scheme for regulating public einployment. ${ }^{172}$ These statutes enumerate different statutory purposes, set forth different rules for employee and employer conduct, and operate through different procedural inechanisms. For example, some statutes refer disputes to PERB and soine, like the MMBA, make no reference to an administrative agency. In cases within PERB's jurisdiction, the agency will determine strike remedies; courts will have to confront the remedies question only if they are called upon to review PERB's decisions. In contrast, cases arising under the MMBA will go directly to the judicial system. At the outset, the courts will have varying degrees of discretion depending on whether or not an administrative agency is involved. Once this jurisdictional question is settled, courts will have to scrutinize the language and rationale of each mdividual statute, and simultaneously try to avoid inconsistency with the rest of the statutory scheme.

169. See supra text accompanying notes $75-78$.

170. See generally R. GoRMAN, supra note 1, at 296-366. For example, an employer may discharge or otherwise discipline an employee who engages in conduct held to be "unprotected." But discharging a worker who engages im "protected" activity is a violation of the National Labor Relations Act § 8(a)(1), 29 U.S.C. \& 158(a)(1) (1976).

171. NLRB v. Local Union 1229 (Jefferson Standard), 346 U.S. 464, 472 (1953).

172. See supra note 6 . 
Second, not all employees are the same. The eight states that have statutorily authorized public employee strikes sonetimes draw distinctions between "essential" and "nonessential" public employees. ${ }^{173}$ Firefighters are often cited as an example of essential public employees. Without the services they provide, the public is immediately exposed to a much higher risk of death, personal injury and property destruction. Other employees perform services that are not as immediately crucial to public health and safety. Although a strike by a city's clerical workers could lead to a disruption of services, great inconvenience, and loss of municipal revenues, it does not pose as great a threat to the public as a firefighters' strike.

Third, strikes arise out of many different kinds of situations. Some strikes arise out of an impasse at the bargaining table: the employees strike in an attempt to gain favorable terms for a collective bargaining agreement. This type of econormic strike is perhaps what first comes to mind when one thinks of a public employee strike.

A different situation arises, however, when workers strike over an alleged unfair labor practice. Courts are more likely to be synpathetic to this kind of strike, and to consider fewer employer remedies appropriate. Previous appellate court opimions have stated that alleged einployer unfair labor practices do not legitimize a pubhic einployee strike under the MMBA. ${ }^{174}$ However, the supreme court suggested in $E l$ Rancho that PERB would be able to take an einployer's unfair labor practices into account in deciding to deny the employer remedies agaimst a strike protesting those practices. ${ }^{175}$

By contrast, a different strike scenario 1might convince a court that more drastic remedies are appropriate. For example, suppose that as part of a collective bargaining agreeinent, a union promises not to strike over specific problems im return for the employer's promise to arbitrate such problems if they should arise. In federal labor law this trade of a no-strike clause for an arbitration clause has been endorsed by the United States Supreme Court as a way to reduce labor strife. ${ }^{176}$ Suppose that one of the problems covered by the no-strike clause arises, and instcad of filing a grievance, the union goes on strike. If a court orders the umion to honor the terms of its collective bargaining contract, it would be difficult for the union to claim that its right to

173. See Hanslowe \& Acierno, supra note 2, at 1079.

174. See, e.g., Stationary Eng'rs, Local 39 v. San Juan Suburban Water Dist., 90 Cal. App. 3d 796, 801, 153 Cal. Rptr. 666, 668 (1979); Almond v. County of Sacramento, 276 Cal. App. 2d 32, 40, 80 Cal. Rptr. 518, 522-23 (1969).

175. El Rancho, 33 Cal. 3d at 958,663 P.2d at 900,192 Cal. Rptr. at 130.

176. See United Steelworkers v. Enterprise Wheel \& Car Corp., 363 U.S. 593 (1960); United Steelworkers v. Warrior \& Gulf Navigation Co., 363 U.S. 574 (1960); United Steelworkers v. American Mfg. Co., 363 U.S. 564 (1960). 
collective bargaining is being violated. Nor can the union clain that a statutory purpose, such as promoting better einployer-employee relations, would be furthered by denying the enployer injunctive rehef. Such a strike imperils the einployer's ability to rely on collective bargaining agreements and thus creates an obstacle to better employeremployee relations. In the hight of society's interest in enforcing collective bargaining agreements, a court would be justified in providing remedies against this type of strike.

The fourth variable is the type of remedy the employer seeks in response to a public enployee strike. Solne remedies are inore severe than others, soine affect policy considerations differently than others, and soine are thouglit to be more effective than others in certain situations. Eacli remedy poses its own questions for the courts.

Damages, for example, is a reinedy which courts will probably be reluctant to grant. Appellate court decisions before the $E l$ Rancho case allowed damages on the ground that employee strikes are illegal. ${ }^{177}$ However, in El Rancho the supreme court implicitly rejected the illegality rule ${ }^{178}$ and expressed its preference for other forms of relief. ${ }^{179}$ Moreover, damages are of limited use to employers durmg a strike. As the court noted in $E l$ Rancho, damages provide relief only after the fact. ${ }^{180}$

An employer's request for an injunction will present a more complicated issue. A strike can be enjoined for reasons other than illegality. For example, a court could enjoin a garbage collectors' strike after a few weeks on the ground that the strike, legal or illegal, poses a threat of irreparable harm to public lealth. The court might note that the Califorma Supreine Court compared injunctive relief favorably to dainages in $E l$ Rancho. ${ }^{181}$ On the other hand, the court might be persuaded that injunctions against strikes infringe on the employees' statutory right to collective bargaining, since they deny einployees the only tactic they can use to convince the employer to negotiate or to accept a specific bargaining proposal. ${ }^{182}$ Injunctions do not merely freeze the status quo, for the passage of time alone may destroy a union's ability

177. See supra text accompanying notes $42-45$.

178. See supra text accompanying notes 136-39.

179. See supra text accompanying notes $118,119$.

180. El Rancho, 33 Cal. 3d at 961, 663 P.2d at 902, 192 Cal. Rptr. at 132.

181. Id.

182. For the argument that the right to strike is necessary to give content to employees' collective bargaining rights, see United Fed'n of Postal Clerks v. Blount, 325 F. Supp. 879, 885 (D.D.C.) (Wright, J., concurring), affd, 404 U.S. 802 (1971); Anderson Fed'n of Teachers, Local 519 v. School City of Anderson, 252 Ind. 558, 571, 251 N.E.2d 15, 22 (1969) (DeBruler, C.J., dissenting), cert. denied, 399 U.S. 928 (1970); School Comm. of Westerly v. Westerly Tcachers Ass'n, III R.1. 96, 108, 299 A.2d 441, 447 (1973) (Roberts, C.J., dissenting); see also Almond, 276 Cal. App. 2d at 35 n.2, 80 Cal. Rptr. at 520 n.2, and the firefighters statute, CAL. LAB. CODE $\S 1962$ (West 1971). 
to stage a successful strike. Employees' enthusiasm, commitment and financial ability to strike may well deteriorate as the dispute continues. And, as a practical matter, the union may not be able to maintain a strike when the mjunction is lifted. Finally, an imjunction may not ensure that essential services will be provided to the public. Even if workers are enjomed from picketing, they cannot be forced to go back to their jobs. ${ }^{183}$

Termmation of striking employees is another problematic remedy. Two appellate court decisions ${ }^{184}$ and a brief statement in Gridley ${ }^{185}$ have proposed termination as a permissible sanction for an illegal strike under the MMBA. Both appellate courts reasoned that since public employee strikes are illegal, striking employees were absent from their jobs without leave and could therefore be fired. ${ }^{186}$ In Gridley the supreme court suggested that termination would be an appropriate remedy if the strike in question were illegal or in breach of contract. ${ }^{187}$ Thus, the supreme court seems to suggest that it is still willing to apply the label of "illegal" to certam categories of strikes. However if the court follows its remedy-based analytic approach in the future and refuses to categorize strikes as legal or illegal, its offer of the termimation remedy may be meaningless. If the court refuses to find a particular strike illegal, it may find the termination remedy in conflict with both the specifically enumerated purposes of the governing statute (for example, promotion of commumication between employers and employees) and the broader policies behind the statutory scheme (for example, promotion of collective bargaining).

\section{An Example of the Case-by-Case Analysis}

Every public employee strike case will present a different combination of these variables. For an example of how a court using the case-by-case approach might be influenced by the statute applicable to the strike, the type of employees involved, the situation giving rise to

From this point of view, firefighters' collective bargaining has no real content. This is arguably acceptable because of the special nature of firefighters' work.

183. See UAW Local 232 v. Wisconsin Employment Relations Bd., 336 U.S. 245, 251 (1949), overruled on other grounds by Lodge 76, Int'l Ass'n of Machinists v. Wisconsin Employment Relations Bd., 427 U.S. 132 (1976); see also Trustees of Cal. State Colleges v. Local 1352, San Francisco State College Fed'n of Teachers, 13 Cal. App. 3d 863, 867, 92 Cal. Rptr. 134, 136-37 (1970).

184. Stationary Eng'rs, Local 39 v. San Juan Suburban Water Dist., 90 Cal. App. 3d 796, 153 Cal. Rptr. 666 (1979); Almond v. County of Sacramento, 276 Cal. App. 2d 32, 80 Cal. Rptr. 518 (1969).

185. 34 Cal. 3d at 204, 666 P.2d at 968, 193 Cal. Rptr. at 526. See supra note 133 and accompanying text.

186. Stationary Engineers, 90 Cal. App. 3d at 800, 153 Cal. Rptr. at 668; Almond, 276 Cal. App. 2d at 35, 80 Cal. Rptr. at 520.

187. Gridley, $34 \mathrm{Cal}$. 3d at 204, 666 P.2d at 968, 193 Cal. Rptr. at 526. 
the strike, and the employer's chosen remedy, consider a case now before the Calfornia Supreme Court.

In County Sanitation District No. 2 v. Los Angeles County Employees' Association, Local $660,{ }^{188}$ sanitation workers struck for eleven days after wage and benefit negotiations reached an impasse. ${ }^{189}$ The workers eventually accepted an offer that the employer had made before the strike. However, the eniployer had already filed an action for mjunctive rehef and damages under the MMBA agamst the workers' union. The appellate court upheld the trial court's award of daniages with some modification in amount. ${ }^{190}$

The supreme court will probably reject the appellate court's rationale in County Sanitation. The appellate court expressly affirmed the dainage award on the theory that all public employee strikes are illegal. ${ }^{191}$ The appellate court cited Pasadena Unified School District $v$. Pasadena Federation of Teachers, Local 1050, ${ }^{192}$ for the proposition that the "conduct of an unlawful strike is itself a tort for which damages may be recovered," 193 and noted the long line of previous appellate decisions establishing the illegality of public employee strikes. ${ }^{194}$ Since the California Suprene Court imphicitly rejected this rule in $E l$ Rancho and Gridley, it should not allow a remedy based solely on the ground that the strike was a public einployee strike and therefore illegal.

Instead, the supreme court will look at all the variables in the County Sanitation situation. In this case there are few compelling reasons to grant the eniployer reinedies. The instant strike was apparently by a recognized bargaining agent and involved negotiations for a new collective bargaining agreement. ${ }^{195}$ The employer was apparently able to provide soine level of public services during the strike. ${ }^{196}$ The sole possible justification for granting a remedy is that sonie violence occurred during the strike. ${ }^{197}$ On the other hand, another factor might encourage the supreme court to deny the remedy sought in the case: the union alleged that the einployer had committed an unfair labor

188. 147 Cal. App. 3d 990, 195 Cal. Rptr. 567, modiffed, 148 Cal. App. 3d 838d (1983), hearing granted, Jan. 5, 1984.

189. Id. at 994,195 Cal. Rptr. at 568.

190. Id. at 1005, 195 Cal. Rptr. at 576.

191. Id. at 995-96, 195 Cal. Rptr. at 570.

192. 72 Cal. App. 3d 100, 140 Cal. Rptr. 41 (1977).

193. County Sanitation, 147 Cal. App. 3d at 996, 195 Cal. Rptr. at 569 (quoting Pasadena Unified School District, 72 Cal. App. 3d at 112, 140 Cal. Rptr. at 48).

194. 147 Cal. App. 3d at 995, 195 Cal. Rptr. at 569.

195. Id. at 994,195 Cal. Rptr. at 568.

196. Id. at 997,195 Cal. Rptr. at 570.

197. Id. at $996 \mathrm{n} .2,195$ Cal. Rptr. at $570 \mathrm{n} .2$. 
practice. ${ }^{198}$ As noted above, courts may be more sympathetic to a strike protesting unfair labor practices. ${ }^{199}$

County Sanitation is probably one of the easier cases the supreme court will have to decide. A harder case would have been presented had the strike lasted long enough to endanger the public health. Furthermore, if there had been clear evidence of violence, if the employer had sought only an mjunction, or if there had been no unfair labor practice allegations, the court's mission would have been far more difficult.

Given the multiplicity of possible strike situations, the suprene court's analytic approach has clear limitations. The court will be able to eliminate those remedies that are granted on the ground that public einployee strikes are illegal. However when illegality is not the only justification, the court will have to measure the remedy against the enuinerated statutory purposes and the broader policies behind the statutory scheine. But these purposes and policies are too ambiguous to provide the court with clear answers under every set of facts. Since the legislature has not been able to create a clear and comprehensive statutory scheine, the court will be forced to pick its way through the maze of strike situations case by case.

\section{CONCLUSION}

From the perspective of employers' remedies, the California Supreme Court's decisions in El Rancho and Gridley have major effects on the right of public employees to strike. El Rancho further cemented the court's preemption doctrine and all but eliminated dainage suits agamst striking teachers' umions by giving PERB exclusive jurisdiction over such claims. Gridley removed the revocation of recognition from the list of permissible employer sanctions agamst striking local employee unions. Although the court did not expressly hold in either case that public employee strikes are legal in California, strikes are now a unore feasible tactic for employees to use in collective bargaining.

These steps are justifiable. Employer-employee relations in California are no longer governed by common law principles. The enactment of statutory collective bargaining inandates a new perspective on those relations. Public einployee strikes are no longer illegal in California under either the statutes or the rationales of the common law.

As justifiable as the court's decisions are, they are only the imitial steps in what promises to be a very difficult journey. El Rancho, Gridley, and even County Sanitation are the easiest fact situations the court

198. Id. at 996-97, 195 Cal. Rptr. at 569-70.

199. See supra text accompanying notes 174-75. 
will have to face; others will inevitably arise in which the court's analytic approach is more difficult to apply. It would have been simpler for the supreme court to have avoided this journey in the first place; under the common law the issue of remedies for public employee strikes was relatively straightforward. But the enactment of public einployee legislation by the California legislature forced the court from that safe haven, and gave the court little guidance on the proper path to follow.

Timothy M. Gill*

* B.A. 1982, University of California, Berkeley; third-year student, Boalt Hall School of Law, University of California, Berkeley. 